\title{
Seabirds of human settlements in Antarctica: A case study of the Mirny Station
}

\author{
Sergey Golubev
}

Papanin Institute for Biology of Inland Waters, Russian Academy of Sciences, Borok, Nekouzskii raion, Yaroslavl oblast, 152742, Russia

\begin{abstract}
Antarctica is free of urbanisation, however, 40 year-round and 32 seasonal Antarctic stations operate there. The effects of such human settlements on Antarctic wildlife are insufficiently studied. The main aim of this study was to determine the organization of the bird population of the Mirny Station. The birds were observed on the coast of the Davis Sea in the Mirny (East Antarctica) from January 8, 2012 to January 7, 2013 and from January 9, 2015 to January 9, 2016. The observations were carried out mainly on the Radio and Komsomolsky nunataks (an area of about $0.5 \mathrm{~km}^{2}$ ). The duration of observations varied from 1 to 8 hours per day. From 1956 to 2016, 13 non-breeding bird species (orders Sphenisciformes, Procellariiformes, Charadriiformes) were recorded in the Mirny. The South polar skuas (Catharacta maccormicki) and Adélie penguins (Pygoscelis adeliae) form the basis of the bird population. South polar skuas are most frequently recorded at the station. Less common are Brown skuas (Catharacta antarctica lonnbergi) and Adélie penguins. Adélie penguins, Wilson's storm petrels (Oceanites oceanicus), South polar and Brown skuas are seasonal residents, the other species are visitors. Adélie penguins, Emperor (Aptenodytes forsteri), Macaroni (Eudyptes chrysolophus) and Chinstrap penguins (Pygoscelis antarctica), Wilson's storm petrels, South polar and Brown skuas interacted with the station environment, using it for comfortable behavior, feeding, molting, shelter from bad weather conditions, and possible breeding. South polar and Brown skuas tend to be attracted to the station, while other Antarctic bird species are indifferent to humans. Birds spend part of the annual cycle at the station or visit it with different frequency, but they cannot meet their ecological needs there all year round. The study improves our understanding of the regularities of the phenomenon of urbanization of the avifauna in the polar regions of the planet Earth.
\end{abstract}

Key words: Antarctic, Haswell Islands, avifauna, urbanisation, nunatak

DOI: $10.5817 / C P R 2021-1-8$

Received January 31, 2021, accepted June 6, 2021.

*Corresponding author: S. V. Golubev<gol_arctic@mail.ru>

Acknowledgements: Author's involvement in obtaining material for this paper was possible thanks to his participation in the $57^{\text {th }}$ and $60^{\text {th }}$ Russian Antarctic expeditions. I would like to express my gratitude to Milos Barták (CPR editor-in-chief) and two anonymous reviewers for their helpful comments on the text of the article. I thank V. S. Gusev for language corrections. 


\section{Introduction}

The environmental changes occurring now are fundamentally different from those at any other time in history; we are changing the Earth more rapidly than we are understanding it (Vitousek et al. 1997, p. 498). The cities, towns and settlements cover $<1 \%$ of the world's surface (Schneider et al. 2010). Globally, more people live in cities $(55 \%$ of the world's population in 2018) than in rural areas, with the urban population likely to reach $68 \%$ by 2050 (see [1] - United Nations 2019). Together with the climate change, urbanization is considered to be one of the largest threats to wildlife (Isaksson 2018). It is well known that human transformation of the land is the main driver of biodiversity loss worldwide, and the consequences of land transformation extend far beyond these areas (Vitousek et al. 1997).

In this respect the Antarctic ecosystems can no longer be regarded as pristine (Znój et al. 2017), because on the Earth's surface there are no longer any ecosystems free from ubiquitous human influence (Vitousek et al. 1997). However, Antarctica remains the only continent on the globe that is still free from urbanization and has the shortest (just over 200 years) history of human activity interactions with wildlife. Antarctica never had indigenous human populations (Chwedorzewska 2009, Znój et al. 2017). However, people have proved to be able to maintain a constant yearround presence there ([2]-COMNAP: Antarctic Station Catalogue 2017). The «cultural landscape of the polar countries» is the youngest on our planet (Uspensky 1959). The impact of human activity in the Northern Hemisphere on the Arctic regions began much earlier than on Antarctica in the Southern Hemisphere. The impact of human activity on the Antarctic environment dates back to the $18^{\text {th }}$ century. The first polar stations appeared there in the late $19^{\text {th }}$ and early $20^{\text {th }}$ centuries. Since then, a new era of sustainable human pres- ence in Antarctica has begun (Tin et al. 2009). Currently, human pressure is clustered predominantly in the Antarctic Peninsula, southern Victoria Land and several areas of East Antarctica (Pertierra et al. 2017).

The first polar station with 10 winterers was established on the Cape Adare (the Borchgrevink expedition) in 1899. However, in 1957-1958, 42 polar stations with 872 winterers already existed in Antarctica (Doubrovin and Petrov 1966). Recently, 72 Antarctic stations (40 year-round and 32 seasonal), 2 seasonal field camps and 2 seasonal field laboratories were recorded there ([2] - COMNAP: Antarctic Station Catalogue 2017, the count of human settlements in Antarctica was made by the author). Humanity in Antarctica has become a factor whose increasing and pervasive impact on the environment and biota is becoming a global problem. Moreover, human-caused changes are still poorly understood and evaluated in terms of threats to Antarctic wildlife.

According to the [3] - British Antarctic Survey (2004), only about $0.34 \%$ of the Antarctic continental zone is free of ice (Tin et al. 2009), while most of the terrestrial biodiversity occupies $<0.5 \%$ of the continent's ice-free territory (Convey et al. 2014, Brooks et al. 2019). An incomparably smaller area is occupied by human settlements in Antarctica, mostly scattered along the coast.

The growth in human activities in Antarctica through research and tourism continues, and it suggests an increasing impact on wildlife. In such circumstances, the value of each patch of land inhabited by terrestrial biota will only increase. In terrestrial Antarctic ecosystems, human activity inevitably causes a higher pressure on certain places on a local scale (Tin et al. 2009), for example, the Mirny Station (Golubev, unpublished data), the Dumont d'Urville Station (Micol and Jouventin 2001) 
or the Fildes Peninsula on the King George Island (Peter et al. 2008). As a result, the habitat undergoes local changes to a greater or lesser extent, and thereby affects the populations of terrestrial vertebrates. It is important to document the human interactions with the surrounding biota, in order to minimize the negative impact on local ecosystems. Our understanding of the above-mentioned interactions is, however, limited, since the targeted research in this field is still insufficient. The research approach to the study of the impact of human settlements on the organization of the bird population, proposed in this article, can partly contribute to improving our knowledge of this phenomenon and management policies in areas of contact between human populations and wildlife.

Currently, the avifaunas of human settlements and their surroundings have been studied to a greater or lesser extent on all continents of our planet (for example, Aronson et al. 2014), including in the polar regions of both hemispheres (Lobanov 1984, Micol and Jouventin 2001, Golubev and Romanov 2007, Wojczulanis-Jakubas et al. 2008). Directional avifaunistic observations related to the influence of hu-

\section{Study area, Material and Methods}

The Haswell archipelago (17 islands and 4 coastal nunataks) is located in the Davis Sea, directly off the coast of Antarctica. The largest of the rocks are the Haswell Island (height $93 \mathrm{~m}$ above sea level, area $0.82 \mathrm{~km}^{2}$ ), and the Komsomolsky and Radio nunataks (Fig. 1). The absolute height is of most of the islands and nunataks is $10-35 \mathrm{~m}$ (Voronov and Klimov 1960). The Haswell Islands support the largest breeding populations of colonial seabirds in the Davis Sea (Golubev 2020a). A total of 9 species of seabirds breed on fast ice near the Haswell Island and on island surface (Golubev 2018). Owing to the abundance of life, Haswell Island, man settlements on bird life in maritime or continental Antarctica were carried out at the Pointe Géologie archipelago, the Arctowski Station, the UAS Akademik Vernadsky (Micol and Jouventin 2001, Chesalin 2007/2008, Chwedorzewska and Korczak 2010, Sierakowski et al. 2017), the Bellingshausen Station (Krylov 1968, Bannash 1984, Kamenev 1987), the Novolazarevskaya Station (Gerbovich 1963), and the Molodezhnaya Station (Dietrich 1979). There is an information about rare sightings of birds at the inland drifting stations Vostok (Petrov and Chernov 1965) and Amundsen-Scott (Sabbatini 2003).

Purposeful survey of the organization of the bird population of the Mirny Station and the study of the impact of human activity on seabirds has not been carried out before. Only fragmentary and unsystematic information about some bird species of this station has been published (for example, Makushok 1959, Kuznetsov 1960, Starck 1980, Mizin 2015, Golubev 2018, 2020a).

The main aim of this study was to determine the organization of the bird population of the Mirny Station and the role of human settlement for visiting seabirds.

along with the adjacent sea ice, has become the Antarctic Specially Protected Area № 127 ([4] - ASPA № 127).

On February 13, 1956, a year-round scientific station (observatory) the Mirny Station was opened on the banks of Pravda, which later served as a base and logistic center for sledge-tracked trains and aircrafts supplying the drifting inland Vostok Station (Savatyugin and Preobrazhenskaya 1999). The station was located at the latitude of the Antarctic Circle, on four marginal nunataks (Komsomolsky, Radio, Morenyy and Hill of the Winds) of the Antarctic continent (Queen Mary Land, Davis Sea, southern Indian Ocean, 
$66^{\circ} 33^{\prime} 11^{\prime \prime} \mathrm{S}, 93^{\circ} 00^{\prime} 35^{\prime \prime} \mathrm{E}$ ), at an altitude of about 40 meters above sea level. The northernmost point of the Mirny is Cape Mabus (Komsomolsky nunatak). Continental ice extends 15-20 meters above sea level between the nunataks. At the location of the station, the ice thickness on the mainland coast is minimal, but gradually increases south of the continent edge. The Mirny nunataks border the sea, and are mostly surrounded by mainland ice (Fig. 1).

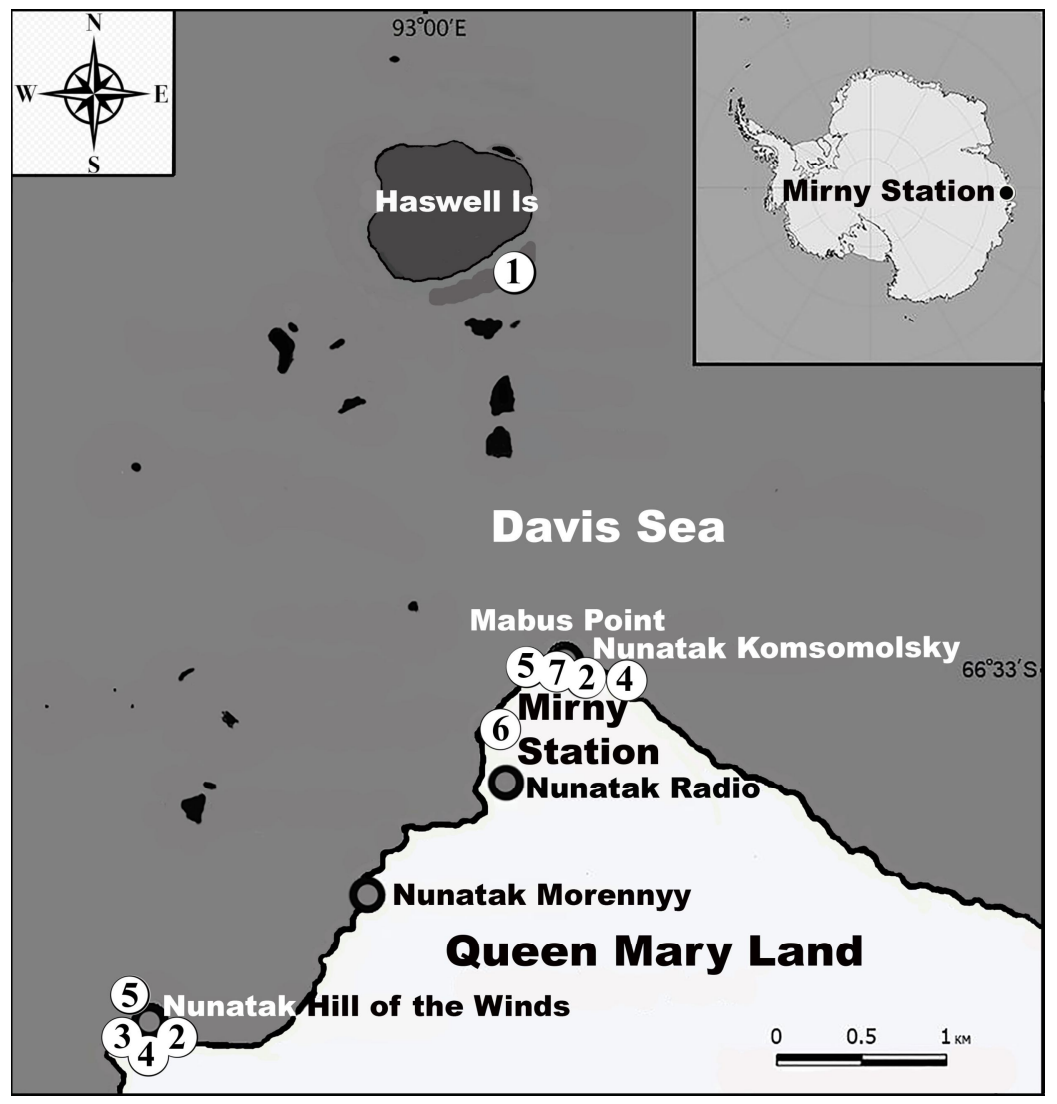

Fig. 1. Study area (in the inset in the upper right corner - the location of the Mirny Station).

Note: the location of the Emperor penguins (Aptenodytes forsteri) colony near Haswell Island (1); moulting sites of Adélie penguins (Pygoscelis adeliae) (2), as well as sites of registration of Chinstrap (Pygoscelis antarctica) (3) and Macaroni (Eudyptes chrysolophus) (4) penguins, Southern giant petrels (Macronectes giganteus) (5), Pomarine skua (Stercorarius pomarinus) (6) and the probable breeding site of Wilson's storm petrels (Oceanites oceanicus) (7) at the Mirny Station. The numbers in circles on the map correspond to the numbers in the legend.

Lichens, mosses and algae grow on the nunataks, but in general, they are almost devoid of vegetation (Savatyugin and Preobrazhenskaya 1999). The surface of the nunataks and the continental ice is con- taminated with oil products and household waste.

Station structures are located on the Komsomolsky, Radio and Morenyy nunataks. The main part of its infrastructure, 
including modules for work and recreation of personnel, is located at the Komsomolsky and Radio nunataks. At the Morenyy nunatak there is an oil storage - two large metal tanks and small structures. The nunatak Hill of the Winds is free of utility structures.

In 1957, up to 169 people wintered in the Mirny, and the population density reached 300 people per $\mathrm{km}^{2}$ (Abakumov and Lupachev 2011/2012). In the mid1960 s, the number of winterers varied from 80 to 100 (Doubrovin and Petrov 1966). Recently, the wintering staff of the station slightly exceeded 20 people.

In the first year of its existence, 21 buildings and 2 runways were built in the Mirny. By 1964, the number of buildings of various types reached 64. Since 1973, the Mirny began to be reconstructed with modular buildings with the use of metal. The number of former buildings gradually decreased. Until very recently, the annual dismantling of old buildings was carried out on a relatively regular basis (Savatyugin and Preobrazhenskaya 1999). However, anthropogenic objects and structures in the Mirny still occupied up to $80 \%$ of the ice-free territory (Abakumov and Lupachev 2011/2012).

Now the Mirny has one-story wooden (Fig. 2) and two-story metal modules for the work and accommodation of station personnel, seasonal research groups (Fig. 3), as well as tanks for storage and use of diesel fuel. From the nunatak Radio in the south-south-west direction $\left(204.5^{\circ}\right)$, a cemetery of technology stretches (broken aircraft, automobile and sea transport, various mechanisms, metal parts, etc.) for $2.7 \mathrm{~km}$ in length and up to $0.5 \mathrm{~km}$ or more in width - a legacy of Soviet times. Depending on the goals set, runways for aviation can be maintained on the fast ice and continental ice near the Mirny.
The Mirny area is characterized by frequent snowstorms and strong catabatic winds. The yearly air temperature average is $-11.30^{\circ} \mathrm{C}$, maximum $+6.80^{\circ} \mathrm{C}$, minimum $-40.30^{\circ} \mathrm{C}$. The average wind speed is $11.2 \mathrm{~m} / \mathrm{s}$, the prevailing wind direction is east-south-east. During the year, on average, 204 days the wind speed in the station area exceeds $15 \mathrm{~m} / \mathrm{s}$. The maximum number of days with storm winds in the Mirny is 247 per year. Around $20-25$ days with a hurricane are noted throughout a year. Low air temperature and wind severely limit the activities of polar explorers. The fast ice near the station is observed most of the year, reaching $30-40 \mathrm{~km}$ in width in September-October. Fast ice breakup usually occurs in mid-February. Steady ice formation in the Davis Sea near the Mirny begins usually in the second ten-day period of March. Fast ice formation occurs when ice thickness is about $20-40 \mathrm{~cm}$. The duration of the onset of stable ice formation before fast ice establishment is about a month [5].

The material for this message was collected by the author in the Mirny from January 8, 2012 to January 7, 2013 and from January 9, 2015 to January 9, 2016. Daily observations were carried out on the Radio and Komsomolsky nunataks (an area of about $0.5 \mathrm{~km}^{2}$ ) - the optimal research platform in the area of increased number of human contacts with birds. Depending on the meteorological conditions, the duration of observations varied from 1 to 8 hours per day. Snowstorms, storms and hurricanes impeded the fieldwork. Most of the observations were made on the

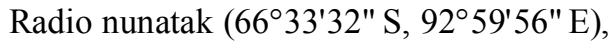
although the Komsomolsky nunatak is more productive for recording birdlife. The nunataks of Morenyy and Hill of the Winds were visited no more than 4 times during the year. 


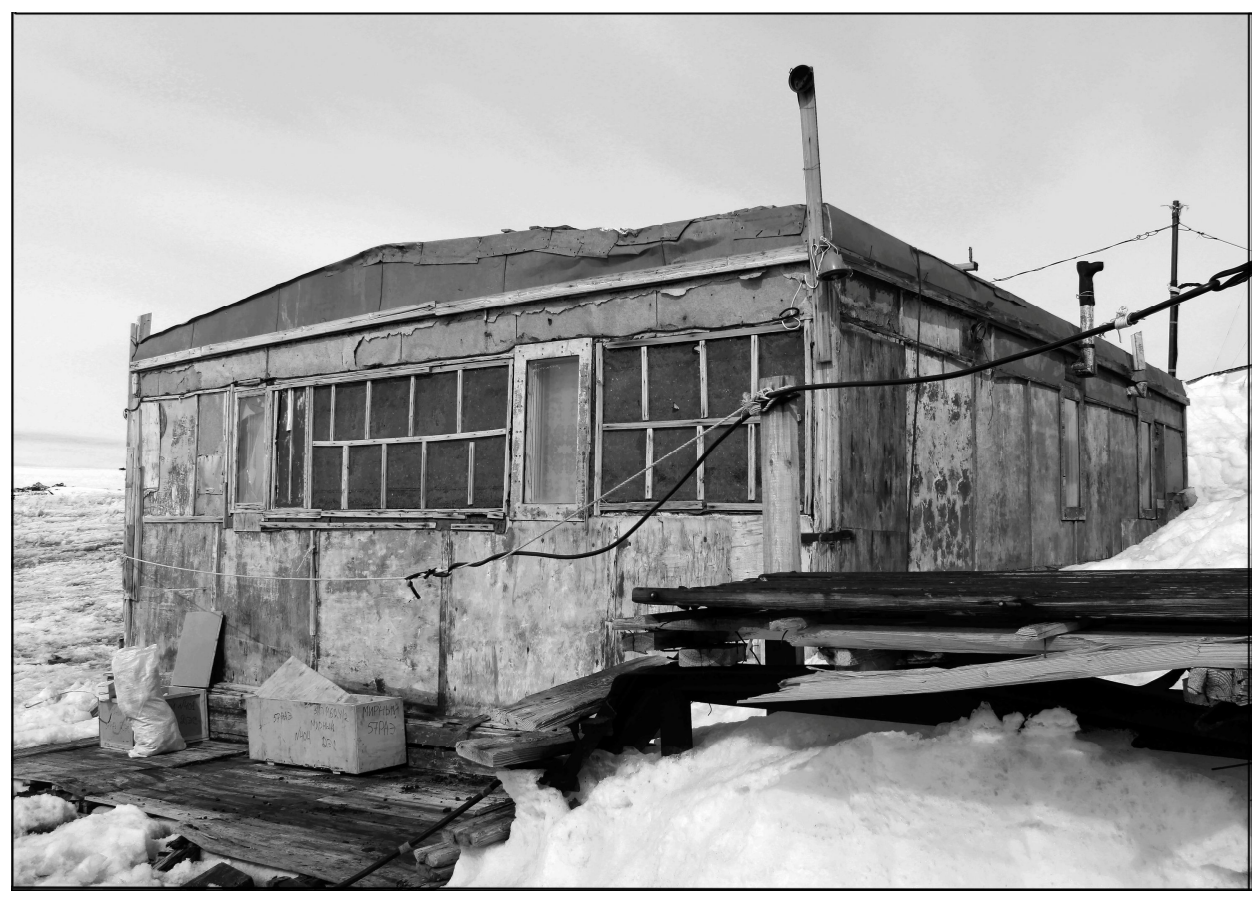

Fig. 2. House No.18. 1956 year of construction. Nunatak Komsomolsky, the Mirny Station. January $12,2012$.

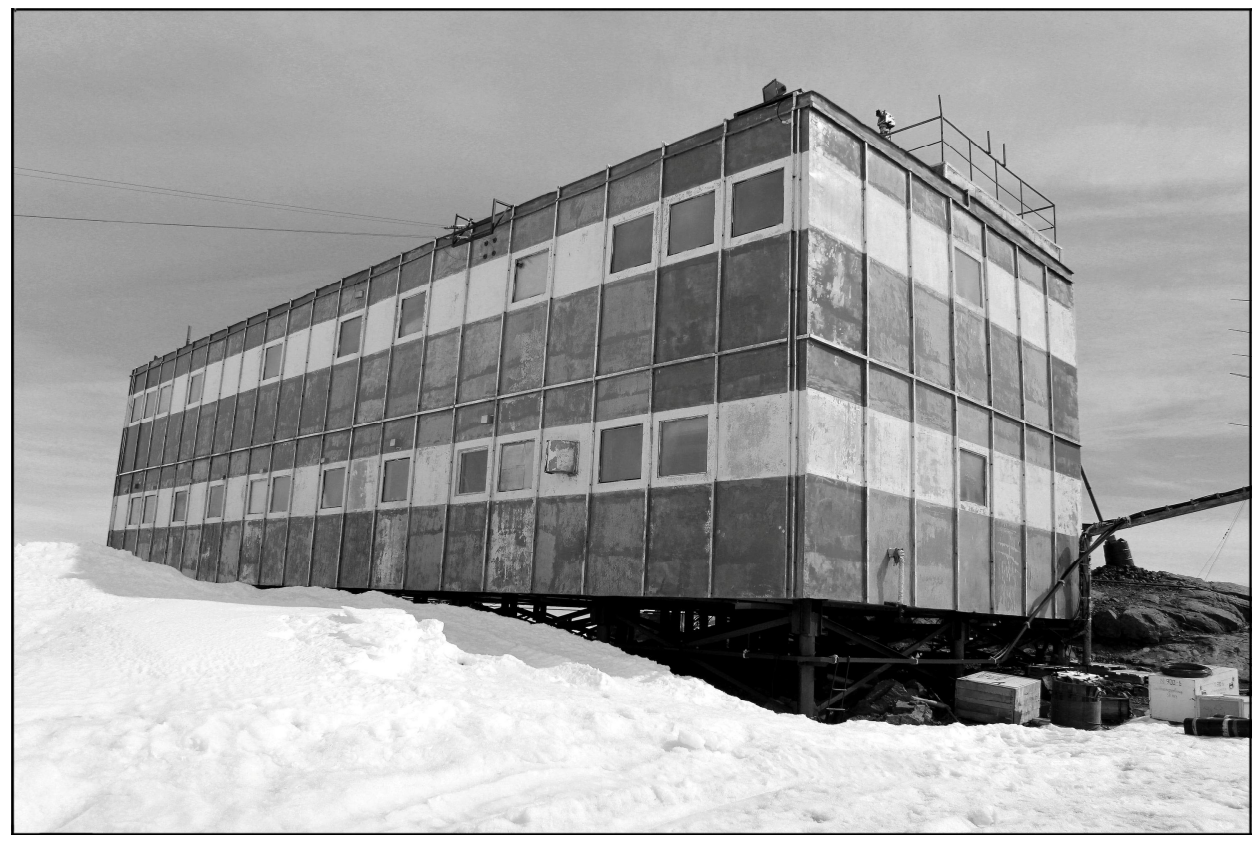

Fig. 3. House of Geophysicists. 1975 year of construction. Nunatak Komsomolsky, the Mirny Station. January 12, 2012. 
Equipment used: binoculars $\times 8-20$; digital cameras Sony Cyber-shot DSC-WX220, Canon-60D, as well as photo lenses Canon 70-200 and Sigma 50-500. With the help of the obtained digital images of objects, the species and the number of flying or swimming birds in groups at long distances, and age (in the cases of Adélie penguins (Pygoscelis adeliae) at molt sites) were determined. The video material made it possible to analyze in office work conditions, the behavior of two species of skuas in the area of human activity. All digital images of the objects presented in this article have been taken by the author.

Few historical data on bird registrations at the Mirny served as a priori information for collecting recent targeted registrations. All individuals found within the station were recorded - from the Hill of the Winds nunatak to the Komsomolsky nunatak, as well as in the sea or on the fast ice in the above section, no further than 50 meters north of the continental ice boundary.

Also, in 2012/2013 and 2015/2016, the

\section{Results and Discussion}

The species diversity of birds, their status in the Haswell archipelago and the Mirny Station, as well as the abundance, seasonal occurrence, the specifics of the

\section{Species diversity}

14 bird species have been recorded in the avifauna of the Haswell Islands. Of these, 13 bird species were recorded at the Mirny Station (Table 1). The sightings of the Chinstrap penguin (Pygoscelis antarctica) and the Pomarine skua (Stercorarius pomarinus) are historical, and the sightings of the other 11 bird species were confirmed by observations in 2012/2013 and $2015 / 2016$. The only invasive species author carried out ringing, color marking of skuas at the station and recorded individuals ringed in previous expeditions by other researchers.

In accordance with the objectives of this study, individuals were considered to interact with the station territory if they used its environment for reproduction, feeding, molting and comfortable behavior. Birds visiting the Mirny in transit - in flight or swimming - were classified as not interacting with the station environment. This approach made it possible to more correctly identify the status of birds that visited the Mirny during the year.

Statistical data were processed in Excel. The comparison of the bird species diversity of the Haswell archipelago and the Mirny Station was made using the Chekanovsky - Serensen faunal similarity index: $K=2 C /(A+B)$, where $A$ and $B$ are the number of bird species in the compared samples, and $\mathrm{C}$ is the number of similar bird species in both samples (Pesenko 1982).

use of the station environment by birds and the influence of human activity were evaluated and are presented in the following section.

included in the Haswell Islands avifauna in the early $21^{\text {st }}$ century was the Brown skua (Catharacta antarctica lonnbergi) (Fig. 4). This species of skuas was first recorded in the Mirny austral summer of 2009/2010 (Mizin 2015). From 2012 to 2016 1-2 mixed pairs of Brown skuas with South polar skuas (Catharacta maccormicki) bred on the Haswell Island (Golubev 2020a). 


\begin{tabular}{|c|l|c|c|}
\hline No. & \multicolumn{1}{|c|}{ Order } & Haswell archipelago & Mirny Station \\
\hline 1. & Sphenisciformes & 4 & 4 \\
\hline 2. & Procellariiforme & 6 & 6 \\
\hline 3. & Charadriiformes & 4 & 3 \\
\hline 4. & $\sum$ & 14 & 13 \\
\hline
\end{tabular}

Table 1. Distribution of avifauna species of the Haswell archipelago (1912-2016) and Mirny Station (1956-2016) according to orders.

According to the data in Tables 1 and 2, the bird species diversity at the Mirny Station and the Haswell archipelago turned out to be almost identical (the Chekanovsky - Serensen faunal similarity index $\mathrm{K}=0.96$ ). The exception is the Kelp gull (Larus dominicanus), which has been observed several times in vicinity of the station, but not on its territory. The high similarity of species diversity is determined by the fact that the Mirny's nunataks are part of the study area, and in the archipelago they were subjected to the attention of biologists more than the others.

The avifauna of the Mirny consists of native species. It is free of non-marine vagrant species, introduced and domesticated bird species, as well as cosmopolitan and synanthropic species such as the Rock dove (Columba livia), House sparrow (Passer domesticus), Common starling (Sturnus vulgaris), and Egyptian heron (Bubulcus ibis). Most species are endemic or subendemic to Antarctica. Only the Holarctic migrant - the Pomarine skua - is a very rare summer visitor to the Mirny. It breeds in the tundra of the northern hemisphere and visits Antarctica during its migration period (Golubev 2020b). The life cycle of most bird species occurs in the southern hemisphere, with the exception of the South polar skuas, Wilson's storm petrels (Oceanites oceanicus), and the Pomarine skuas undergoing transequatorial migrations.

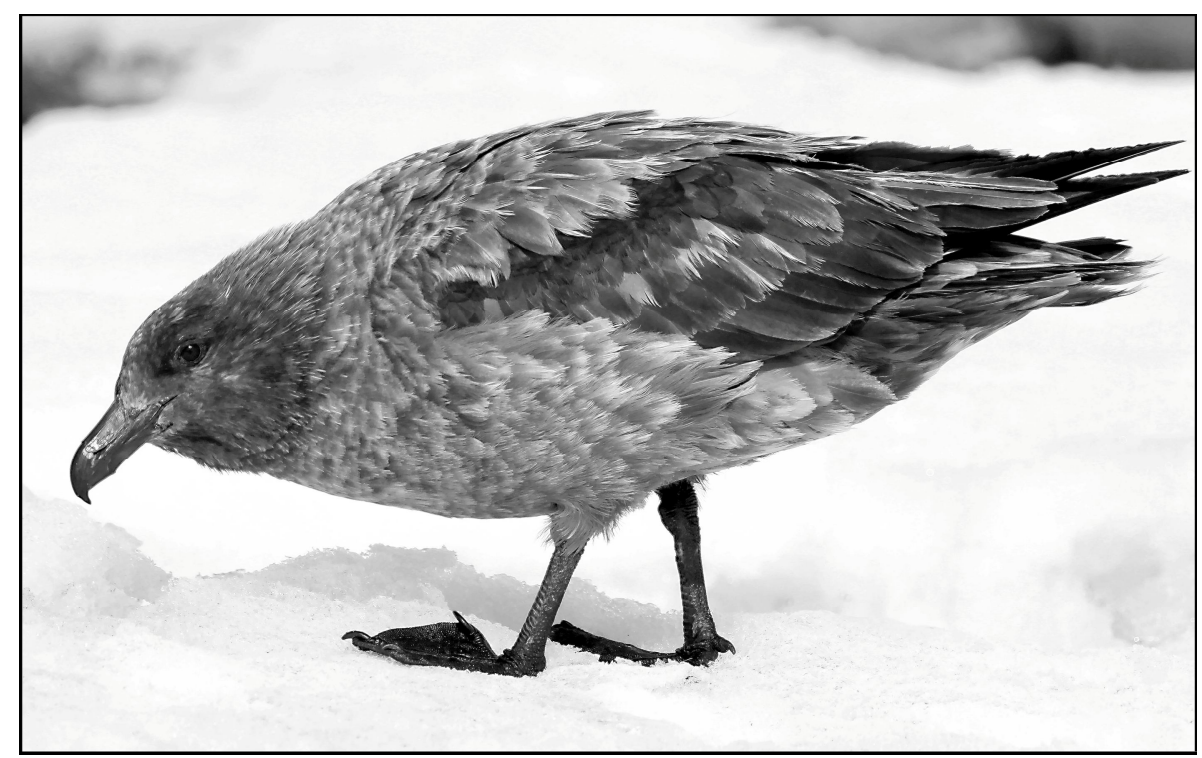

Fig. 4. Brown skua (Catharacta antarctica lonnbergi). Nunatak Radio, the Mirny Station. January $11,2012$. 


\section{Species status}

Data presented in Table 2 show significant differences between the status of bird species of the Haswell Islands and the Mirny. For example, on the archipelago of 14 bird species, the populations of 9 species breed annually. The other 5 species (vagrants and visitors) have the status of non-breeding. They visit this area from time to time. All 9 species of birds breeding on the archipelago do not breed at the station (except for the probable breeding of one pair of Wilson's storm petrels), but visit its territory, and their statuses in the Mirny are inherently unequal. For example, all the tube-nosed bird species breeding on the Haswell Islands, as well as Emperor penguins (Aptenodytes forsteri), are visitors at the station. Along with this, Adélie penguins are considered seasonal residents, since they molt annually within the
Mirny on the mainland ice and the Komsomolsky and Hill of the Winds nunataks. Outside of molting, Adélie penguins visit the station territory only occasionally. Observations of ringed and plastic tagged South polar and Brown skuas have shown that some are very frequent in summer, sometimes almost daily. Such individuals can be considered summer residents. Nonresident skuas were once observed at the station during the breeding season, and twice or several times as visitors.

Lastly, on the islands of the archipelago and in the Mirny, the absolute identity of the statuses was revealed exclusively in vagrant and visitor avian species (Chinstrap and Macaroni (Eudyptes chrysolophus)) penguins, Southern giant petrels (Macronectes giganteus), and Pomarine skuas) that briefly visit the study area (Table 2).

\begin{tabular}{|c|c|c|c|}
\hline No. & Bird species & Haswell archipelago & Mirny Station \\
\hline 1. & Aptenodytes forsteri & $\mathrm{BR}$ & NBR, V \\
\hline 2. & Pygoscelis adeliae & $\mathrm{BR}$ & NBR, V, SR \\
\hline 3. & Pygoscelis antarctica & NBR, V & NBR, V \\
\hline 4. & Eudyptes chrysolophus & NBR, V & NBR, V \\
\hline 5. & Fulmarus glacialoides & $\mathrm{BR}$ & NBR, V \\
\hline 6. & Thalassoica antarctica & $\mathrm{BR}$ & NBR, V \\
\hline 7. & Daption capense & $\mathrm{BR}$ & NBR, V \\
\hline 8. & Pagodroma nivea & $\mathrm{BR}$ & NBR, V \\
\hline 9. & Macronectes giganteus & NBR, V & NBR, V \\
\hline 10. & Oceanites oceanicus & $\mathrm{BR}$ & BR?, NBR, V, SR \\
\hline 11. & Stercorarius pomarinus & NBR, V & NBR, V \\
\hline 12. & Catharacta maccormicki & $\mathrm{BR}$ & NBR, V, SR \\
\hline 13. & Catharacta antarctica & $\mathrm{BR}$ & NBR, V, SR \\
\hline 14. & Larus dominicanus & NBR, V & - \\
\hline
\end{tabular}

Table 2. Status of bird species in the avifauna of the Haswell archipelago and Mirny Station. Note: BR - breeding; NBR - non-breeding; BR? - probably breeding; SR - seasonal resident; $\mathrm{V}$ - visitor. All non-breeding bird species (vagrants and visitors) are grouped into the category of visitor species $(\mathrm{V})$. 


\begin{abstract}
Abundance
The basis of the Mirny's bird population is formed by the bird species interacting with the station environment - the South polar skuas and Adélie penguins. The abundance of South polar skuas varied for most of the season from 1-2 individuals to several dozen individuals (Golubev 2018). At the same time, the number of Adélie penguins during the molt period (February-March) significantly exceeded the number of South polar skuas. The maximum number of simultaneously molting Adélie penguins at the Komsomolsky nu-

natak exceeded 200 individuals. Several dozen of these penguins molted at the Hill of Winds (Golubev, unpublished data). The proportion of Wilson's storm petrels (1 pair) and Brown skuas (usually 1 or 2 individuals) in the total abundance of birds is insignificant. The abundance of Emperor penguins on the periphery of the station could very rarely reach high values if their groups left the colony for a short time and formed clusters of tens or hundreds of individuals (Table 3 ) on the fast ice at the Cape Mabus.
\end{abstract}

\begin{tabular}{|c|l|c|c|c|c|}
\hline No. & \multicolumn{1}{|c|}{ Bird species } & min-max & $\mathbf{m} \pm$ SD & Median & n \\
\hline 1. & Aptenodytes forsteri & $1-200$ & $26,3 \pm 41,3$ & 16 & 23 \\
\hline 2. & Fulmarus glacialoides & $1-16$ & $2,5 \pm 2,9$ & 1 & 77 \\
\hline 3. & Thalassoica antarctica & $1-59$ & $9,4 \pm 14,6$ & 4 & 16 \\
\hline 4. & Daption capense & $1-4$ & $1,9 \pm 1,0$ & 2 & 13 \\
\hline 5. & Pagodroma nivea & $1-38$ & $3,2 \pm 4,2$ & 2 & 127 \\
\hline 6. & Oceanites oceanicus & $1-8$ & $1,9 \pm 1,5$ & 1 & 59 \\
\hline
\end{tabular}

Table 3. Size of groups of Emperor penguins (Aptenodytes forsteri) and tube-nosed bird species encountered in the territory of the Mirny Station in 2012/2013 and 2015/2016. Note: for Wilson's storm petrels (Oceanites oceanicus), the table shows the number of individuals simultaneously observed at the station.

\title{
Seasonal occurrence of bird species
}

There were no wintering bird species in the Mirny Station, as well as those found there daily throughout the year. Two species, i.e. the Emperor penguin and the Snow petrel (Pagodroma nivea), visited the station during all seasons of the year, including winter. The remaining 11 species

\section{Bird presence at the station}

Most bird species cannot meet their ecological needs in the territory of the Mirny Station all year round. Therefore, they spend only part of their annual cycle (penguins, tube-nosed bird species, and skuas) were recorded from spring to autumn, i.e., in the pre-breeding, breeding and post-breeding periods. Chinstrap and Macaroni penguins, Southern giant petrels, skuas and Cape petrels (Daption capense) were seen only in summer (Table 4).

at the station (for example, the Adélie penguin and Wilson's storm petrel) or visit it with varying frequencies. 


\begin{tabular}{|c|c|c|c|}
\hline No. & Bird species & $2012 / 2013$ & $2015 / 2016$ \\
\hline 1. & Aptenodytes forsteri & $09.04-14.12$ & $18.01-08.11$ \\
\hline 2. & Pygoscelis adeliae & $\begin{array}{l}31.01-30.03 \\
13.12-26.12\end{array}$ & $\begin{array}{l}27.01-31.03, \\
31.10-07.01\end{array}$ \\
\hline 3. & Eudyptes chrysolophus & $02-17.02$ & - \\
\hline 4. & Fulmarus glacialoides & $\begin{array}{l}12.01-12.04 \\
27.09-02.01\end{array}$ & $\begin{array}{l}08.02-30.03, \\
29.11-07.01\end{array}$ \\
\hline 5. & Thalassoica antarctica & $\begin{array}{l}09.04-13.05 \\
25.10-02.01\end{array}$ & $06-31.12$ \\
\hline 6. & Daption capense & $23.11-05.12$ & $09-25.12$ \\
\hline 7. & Pagodroma nivea & $\begin{array}{l}6.02-20.05 \\
20.10-26.12 \\
\end{array}$ & $\begin{array}{c}10.01-29.04,18.07 \\
08.11-22.12\end{array}$ \\
\hline 8. & Macronectes giganteus & 15.02 & 11.02 \\
\hline 9. & Oceanites oceanicus & $\begin{array}{l}09.01-25.02 \\
22.11-30.12\end{array}$ & $\begin{array}{l}10.01-02.03 \\
24.11-25.12\end{array}$ \\
\hline 10. & Catharacta maccormicki & $\begin{array}{c}08.01-13.04 \\
02.10-07.01\end{array}$ & $\begin{array}{l}09.01-03.04 \\
14.10-08.01\end{array}$ \\
\hline 11. & Catharacta antarctica & $\begin{array}{c}08.01-11.03 \\
12.10-06.01\end{array}$ & $\begin{array}{l}18.01-19.03 \\
16.10-09.01\end{array}$ \\
\hline
\end{tabular}

Table 4. Dates of sightings of bird species at the Mirny Station in 2012/2013 and 2015/2016.

During 2012/2013 and 2015/2016, the total number of days with a visit to the station by species of birds was 863 , of which 460 were recorded in summer, 212 in autumn, 7 in winter, 184 in spring. Thus, bird visits to the Mirny are at their peak in summer, minimal in winter, and more than two times less in autumn and spring when compared with the summer months. In the course of two-year observations it was also established that during the year, the Mirny is most often visited by South polar skuas, much less often by Brown skuas and Adélie penguins, and even less often by Snow petrels, Southern fulmars (Fulmarus glacialoides) and Wilson's storm petrels. The most rare in terms of attendance were
Emperor and Macaroni penguins, Southern giant petrels, Antarctic (Thalassoica antarctica) and Cape petrels (Table 5).

Almost all visitor species were not normally observed in the Mirny around the clock. The longest, multi-day and roundthe-clock presence at the station was observed in molting Adélie penguins and, apparently, in Wilson's storm petrels (probable breeding). Wandering Chinstrap and Macaroni penguins spent up to several days at the station. Very rarely, several South polar skuas spent the night at the station under favorable meteorological conditions of the Antarctic summer and could have been observed during the day.

\section{The nature of the use of the station environment by birds}

The above facts indicate that only 7 bird species - the Emperor penguin and the Adélie penguin, Macaroni and Chinstrap penguins, Wilson's storm petrel, South polar and Brown skuas interact with the station environment, using it for comforta- ble behavior, feeding, molting, as well as places of shelter from bad weather, and possible breeding. All other bird species visit the Mirny for a short time, in transit, in flight, without coming into direct contact with the environment of the station. 


\begin{tabular}{|c|c|c|c|c|c|c|}
\hline Bird species & Year & Summer & Autumn & Winter & Spring & $\sum$ \\
\hline \multirow{2}{*}{ Aptenodytes forsteri } & $2012 / 2013$ & 1 & 2 & 1 & 3 & 7 \\
\hline & $2015 / 2016$ & 1 & - & 5 & 9 & 15 \\
\hline \multirow{2}{*}{ Pygoscelis adeliae } & $2012 / 2013$ & 31 & 30 & - & - & 61 \\
\hline & $2015 / 2016$ & 23 & 30 & - & 2 & 55 \\
\hline \multirow{2}{*}{$\begin{array}{l}\text { Eudyptes } \\
\text { chrysolophus }\end{array}$} & $2012 / 2013$ & 11 & - & - & - & 11 \\
\hline & $2015 / 2016$ & - & - & - & - & - \\
\hline \multirow{2}{*}{$\begin{array}{l}\text { Fulmarus } \\
\text { glacialoides }\end{array}$} & $2012 / 2013$ & 6 & 14 & - & 3 & 23 \\
\hline & $2015 / 2016$ & 16 & 15 & - & 1 & 32 \\
\hline \multirow{2}{*}{$\begin{array}{l}\text { Thalassoica } \\
\text { antarctica }\end{array}$} & $2012 / 2013$ & 4 & 6 & - & 2 & 12 \\
\hline & $2015 / 2016$ & 6 & - & - & - & 6 \\
\hline \multirow{2}{*}{ Daption capense } & $2012 / 2013$ & 1 & - & - & 3 & 4 \\
\hline & $2015 / 2016$ & 7 & - & - & - & 7 \\
\hline \multirow{2}{*}{ Pagodroma nivea } & $2012 / 2013$ & 9 & 21 & - & 7 & 37 \\
\hline & $2015 / 2016$ & 16 & 8 & 1 & 13 & 38 \\
\hline \multirow{2}{*}{$\begin{array}{l}\text { Macronectes } \\
\text { giganteus }\end{array}$} & $2012 / 2013$ & 1 & - & - & - & 1 \\
\hline & $2015 / 2016$ & 1 & - & - & - & 1 \\
\hline \multirow{2}{*}{ Oceanites oceanicus } & $2012 / 2013$ & 30 & - & - & 2 & 32 \\
\hline & $2015 / 2016$ & 22 & 1 & - & 2 & 25 \\
\hline \multirow{2}{*}{$\begin{array}{l}\text { Catharacta } \\
\text { maccormicki }\end{array}$} & $2012 / 2013$ & 88 & 40 & - & 49 & 177 \\
\hline & $2015 / 2016$ & 85 & 31 & - & 41 & 157 \\
\hline \multirow{2}{*}{ Catharacta antarctica } & $2012 / 2013$ & 43 & 6 & - & 17 & 66 \\
\hline & $2015 / 2016$ & 58 & 8 & - & 30 & 95 \\
\hline
\end{tabular}

Table 5. Seasonal distribution of the number of days with the presence of a bird species in the Mirny in 2012/2013 and 2015/2016.

\section{Influence of human activities on birds}

Until the arrival of the Australian Antarctic Expedition to the archipelago in 1912 (Mawson 1915), the local landscape was free of human activity. Natural habitats were preserved until the middle of the $20^{\text {th }}$ century. During the Soviet period (from 1956 to 1991), the local ecosystem experienced strong human pressure from the activity of the Soviet Antarctic expeditions. Land changes and erection of anthropogenic structures (construction of the
Mirny Station, fuel storage facilities at the Komsomolsky and Morenyy nunataks), chemical pollution (operation of diesel generators, local oil spills, preparation of tracked vehicles in the Mirny for trips to the Vostok Station), and the main factors of impact human activity on birds in the Mirny were of direct concern. However, during the work of the Russian Antarctic expedition (from 1991 to the present), the anthropogenic pressure signifi- 
cantly decreased due to the gradual dismantling of old buildings, a decrease in the number of wintering personnel of polar explorers, a decrease in fuel consumption by diesel generators for the station's needs, the cancellation of tracked vehicles to the Vostok Station and environmental protection measures. It is difficult to make a judgement about the changes in the avifauna of the Mirny that have taken place over a period of more than a century long, since the description of the initial, reference state of the birds inhabiting the coastal nunataks has not been made. However, it is known that the continental icefree nunataks in the immediate vicinity of the Mirny were not inhabited by birds by the beginning of the $60 \mathrm{~s}$ of the $20^{\text {th }}$ century (Pryor 1968). In the subsequent period, i.e. until 2016, the nunataks had not been inhabited by breeding birds, with the exception of the likely breeding of a pair of Wilson's storm petrels. From the 2005/ 2006 season (Mizin 2010, data from the author and station staff) and until 2016, a pair of storm petrels regularly occupied the same crevice during the breeding season on the Komsomolsky nunatak. The new breeding site of the Wilson's storm petrels at the nunatak Komsomolsky may have appeared due to changes in the distribution of snow masses, which provided access to the hollow in the cliff crevice at the beginning of breeding period.

Published information on the encounters of Emperor penguins and tube-nosed bird species at the station could not be found. However, at the Cape Mabus, molting Adélie penguins have been document-

\section{Pollution}

Until 1956, the coastal nunataks of the Haswell archipelago were free from pollution. Pollution that affected birds was not documented in the course of the Soviet Antarctic expedition. The first facts of the influence of oil products on Antarctic birds in the Mirny were obtained during the ed from 1956-1957(Kuznetsov 1960). Their number has not been reported. Therefore, the changes in the abundance of molting Adélie penguins cannot be compared with their recent abundance in the Mirny Station. As these penguins continued to molt until recently, their status as seasonal station residents remained unchanged during 1956-2016. There was also a mention of sightings of Southern fulmars in the Mirny Station in 1958 (Makushok 1959). Southern fulmars, along with other tube-nosed bird species, continue to be recorded at the station. Their status as non-breeding visitor species has not changed during the historical period either. Prior to 1956, South polar skuas may not have visited uninhabited shore nunataks too frequently. At the same time, with the formation of the station, the frequency of occurrence, duration of stay, and the total number of South polar skuas, food generalists, attracted by the available food waste in the Mirny Station increased (Starck 1980, Mizin 2015, Golubev 2018).

Nunataks had been undoubtedly used by Adélie penguins for molting and vagrant penguins for recreation before the human activities started there. This area may have been visited by South polar skuas, tube-nosed bird species and Emperor penguins. Most likely, human activities could only noticeably affect Adélie penguins (disturbance of molting birds, pollution) and skuas (food waste). A radical change in the environment in the Mirny did not lead to the disappearance of individual populations of Antarctic birds.

activity of the Russian Antarctic expedition in 1999/2000. Further, the facts of contamination of birds with oil were recorded by other biologists until 2015/2016 inclusive. Oil contamination of molting Adélie penguins and vagrant Macaroni penguins has been identified at Cape Ma- 
bus (Mizin 2010, Mizin and Chernov 2000, Golubev, unpublished data). In addition, the interactions of seabirds with macroplastics at the station have been established. The entanglement of the Adélie penguin in a ball of fishing line and the ingestion of plastic by the South polar skua was documented by Golubev (2020b). No negative impact of artificial light and station noise sources - diesel generators and tracked vehicles - on birds was revealed.

\section{Conclusion}

1. Human activities, in general, did not affect the behavior of tube-nosed bird species and Antarctic penguins. However, some Emperor penguins and Adélie penguins may have an explicit short-term curiosity about the human presence.

2. The behavior of South polar and Brown skuas shows us some tendency towards synanthropization.

3. Among all bird species encountered at the Mirny Station, South polar skuas, Brown skuas and penguins show maximum tolerance to the close human presence.

3. The number and strength of connections between South polar and Brown skuas with the territory of the Mirny Station depend on the composition of kitchen
Thus, with the advent of human activity, plastic and oil pollution have become new challenges for Antarctic birds at the Mirny. Cleaning the rocky surfaces of Cape Mabus from oil pollution, correct disposal of plastic that annually arrives at the Mirny with every consecutive expedition, upgrading of the station's vehicle fleet with new transport will reduce the risks of the negative impact of the aforementioned pollution on birds. waste, their abundance and availability.

4. The positive trend in the increase in the abundance of Brown skuas in the Haswell archipelago and in the frequency of their occurrence in the Mirny may persist.

5. The abundance of South polar skuas at the Mirny is likely to decline in the coming years. This will be made possible by measures to control the disposal of kitchen waste without skuas having access to it.

6. The trends in the abundance of most bird species visiting the territory of the Mirny will most likely be influenced by natural environmental factors at a low and decreasing anthropogenic load.

\section{References}

Abakumov, E. V., Lupachev, A. V. (2011/2012): Soil diversity of terrestrial ecosystems in Antarctica (in the areas where Russian Antarctic stations are located). Ukrainian Antarctic Journal, 10-11: 222-228. (In Russian).

Aronson, M. F. J., Frank, A., La Sorte, F. A., Nilon, C. H., Katti, M., Goddard, M. A., Lepczyk, C. A., Warren, P. S., Williams, N. S. G., Cilliers, S., Clarkson, B., Dobbs, C., Dolan, R., Hedblom, M., Klotz, S., Kooljmans, J. L., KüHn, I., Macgregor-Fors, I., Mcdonnell, M., Mörtberg, U., Pyšek, P., Siebert, S., Sushinsky, J., Werner, P. and WINTER, M. (2014): A global analysis of the impacts of urbanization on bird and plant diversity reveals key anthropogenic drivers. Proceedings of the Royal Society B: Biological Sciences, 281: 20133330. doi: 10.1098/rspb.2013.3330.

BANNASH, R. (1984): Zoological research in the area of Bellingshausen station. Newsletter of the Soviet Antarctic Expedition, 105: 37-42. (In Russian).

Brooks, S. T., Tejedo, P. and O'NeILl, T. A. (2019): Insights on the environmental impacts associated with visible disturbance of ice-free ground in Antarctica. Antarctic Science, 31(6): 304-314. doi: 10.1017/S0954102019000440. 
Convey, P., Chown, S. L., Clarke, A., Barnes, D. K. A., Bokhorst, S., Cummings, V., Ducklow, H. W., Frati, F., Green, T. G. A., Gordon, S., Griffiths, H. J., HowardWilliams, C., Huiskes, A. H. L., Laybourn-Parry, J., Lyons, W. B., Mcminn, A., Morley, S. A., Peck, L. S., Quesada, A., Robinson, S. A., Schiaparelli, S. and Wall, D. H. (2014): The spatial structure of Antarctic biodiversity. Ecological Monographs, 84: 203-244.

CHESALIN, M. V. (2007/2008): Long-term changes in bird populations in the area of the Ukrainian Antarctic station Akademik Vernadsky. Ukrainian Antarctic Journal, 6-7: 110-118. (In Russian).

Chwedorzewska, K. J. (2009): Terrestrial Antarctic ecosystems in the changing world: An overview. Polish Polar Research, 30(3): 263-276. doi: 10.4202/ppres.2009.13.

Chwedorzewska, K. J., KorczaK, M. (2010): Human impact upon the environment in the vicinity of Arctowski Station, King George Island, Antarctica. Polish Polar Research, 31(1): 45-60. doi: 10.4202/ppres.2010.04.

Dietrich, R. (1979): Death of Adélie penguin chicks in the area of Molodezhnaya station. Newsletter of the Soviet Antarctic Expedition 99: 85-87. (In Russian).

Doubrovin, L. I., Petrov, V. N. (1966): Antarctic population. Soviet Antarctic Expedition Bulletin, 58: 59-61.

Gerbovich, V. I. (1963): Adélie penguins in the Schirmacher Oasis. Newsletter of the Soviet Antarctic Expedition, 39: 45. (In Russian).

Golubev, S. V. (2018): Injuries of webs on the feet of south polar skuas Catharacta maccormicki: Results of studying active obliged aggregations. American Journal of Life Sciences, 6(5): 6573. doi: $10.11648 /$ j.ajls.20180605.12.

Golubev, S. (2020a): Vagrants and visitors in the avifauna of the Haswell archipelago, East Antarctica. Polish Polar Research, 41(2): 23-36. doi: 10.24425/ppr.2020.133010.

Golubev, S. (2020b): Macroplastic in seabirds at Mirny, Antarctica. Birds 1(1): 13-18. doi: 10.3390/birds 1010003 .

Golubev, S. V., Romanov, A. A. (2007): Some data on the birds of the city of Norilsk and its environs. In: A. A. Romanov (ed.): Biodiversity of ecosystems of the Putorana plateau and adjacent territories. Working Group on Anseriformes of Northern Eurasia, State Natural Reserve "Putoransky", Moscow, pp. 71-91. (In Russian).

IsAKSSON, C. (2018): Impact of urbanization on birds. In: D. T. Tietze (ed.): Bird species: How they arise, modify and vanish. Fascinating Life Sciences Series. Springer, Berlin, pp. 235-257.

Kamenev, V. M. (1987): Avifauna of Fildes Peninsula, King George Islands (South Shetland Islands). Newsletter of the Soviet Antarctic Expedition, 109: 72-80. (In Russian).

KRYLOV, V. I. (1968): Marine mammals and birds in the area of Bellingshausen station. Newsletter of the Soviet Antarctic Expedition, 71: 68-70. (In Russian).

Kuznetsov, M. A. (1960): On the "curiosity" of Adélie penguins. Newsletter of the Soviet Antarctic Expedition, 22: 61-63. (In Russian).

LoBANOV, V. A. (1984): Bird population of Vorkuta and its possible changes. In: R.-V. F. Idzelis, R. E. Patapavichus (eds.): Birds and urbanized landscape. Kaunas, pp. 90-91. (In Russian).

MAKUSHOK, V. M. (1959): On biological collections and observations at the Mirny Observatory in 1958. Newsletter of the Soviet Antarctic Expedition, 6: 40-42. (In Russian).

Mawson, D. (1915): The home of the blizzard: Being the story of the Australian Antarctic Expedition, 1911-1914. Volume 2. William Heinemann, London, 339 p.

Micol, T., Jouventin, P. (2001): Long-term population trends in seven Antarctic seabirds at Pointe Géologie (Terre Adélie). Human impact compared with environmental change. Polar Biology, 24(3): 175-185. doi: 10.1007/s003000000193.

Mizin, I. A. (2010): Report on the environmental protection program at Mirny Station in the $54^{\text {th }}$ RAE. Unpublished report. (In Russian).

Mizin, I. A. (2015): South polar skua Catharacta maccormicki near the Mirny Station (Antarctica) in 2009-2010. The Russian Ornithological Journal, 24(1106): 499-505. (In Russian).

Mizin, YU. A., CheRnov, A. (2000): Report on the ecological and environmental research program conducted by $44^{\text {th }}$ RAE at the Mirny Observatory. Unpublished report. (In Russian). 
Pertierra, L. R., Hughes, K. A., Vega, G. C. and Olalla-TÁrraga, M. Â. (2017): High resolution spatial mapping of human footprint across Antarctica and its implications for the strategic conservation of avifauna. PLoS ONE, 12(1): e0168280. doi:10.1371/journal.pone.0168280.

Pesenko, Yu. A. (1982): Principles and methods of faunistic research. Nauka, Moscow, USSR, 277 p. (In Russian).

Peter, H.-U., Buesser, C., Mustafa, O. and Pfeiffer, S. (2008): Risk assessment for the Fildes Peninsula and Ardley Island, and development of management plans for their designation as Specially Protected or Specially Managed Areas. Umweltbundesamt Research Report; 20313 124, UBA-FB 001155e, Texte 20/08.

Petrov, V., Chernov, B. (1965): An unexpected guest. Newsletter of the Soviet Antarctic Expedition, 55: 56-58. (In Russian).

PrYOR, M. E. (1968): The avifauna of Haswell Island, Antarctica. In: O. L. Austin (ed.): Antarctic bird studies. Antarctic Research Series 12. American Geophysical Union, Washington, pp. 57-82.

Sabbatini, M. (2003): Non-human life form seen at Pole. The Antarctic Sun January, 5: 3.

Savatyugin, L. M., Preobrazhenskaya, M. A. (1999): Russian research in Antarctica. Volume 1: 1-20 Soviet Antarctic Expedition. Hydrometeoizdat, Saint Petersburg, Russia, 359 p. ISBN: 5-286-01265-5. (In Russian).

SCHNeIDER, A., Friedl, M. A. and Pootere, D. (2010). Mapping global urban areas using MODIS 500-m data: New methods and datasets based on «urban ecoregions». Remote Sensing of Environment, 114(8): 1733-1746. doi: 10.1016/j.rse.2010.03.003.

SIERAKOWSKI, K., KORCZAK-ABSHIRE, M. and JADWISCZAK, P. (2017): Changes in bird communities of Admiralty Bay, King George Island (West Antarctic): insights from monitoring data (19771996). Polish Polar Research, 38(2): 231-262. doi: 10.1515/popore-2017-0010.

StARCK, W. (1980): The avifauna of Haswell Island (East Antarctica) in summer of 1978/79. Polish Polar Research, 1(2-3): 183-196.

Tin, T., Fleming, Z., Hughes, K., Ainley, D., Convey, P., Moreno, C. A., Pfeiffer, S., Scott, J. and SNAPE, I. (2009): Impacts of local human activities on the Antarctic environment. Antarctic Science, 21(1): 3-33. doi:10.1017/S0954102009001722.

USPENSKY, S. M. (1959): Features of the avifauna of the cultural landscape of the Arctic and Subarctic. Ornithology, 2: 7-15. (In Russian).

Vitousek, P. M., Mooney, H. A., Lubchenco, J. and Melillo, J. M. (1997): Human domination of Earth's ecosystems. Science, 277: 494-499.

Voronov, P. S., Kuimov, L. V. (1960): Geological structure of the Mirny area. Soviet Antarctic Expedition, 9: 185-196. (In Russian).

Wojczulanis-Jakubas, K., Jakubas, D. and Stempniewicz, L. (2008): Avifauna of Hornsund area, SW Spitsbergen: Present state and recent changes. Polish Polar Research, 29(2): 187-197.

Znój, A., Chwedorzewska, K. J., Androsiuk, P., Cuba-Diaz, M., Gielwanowska, I., Koc J., KorcZaK-Abshire, M., GrZesiaK, J. and ZMarZ, A. (2017): Rapid environmental changes in the Western Antarctic Peninsula region due to climate change and human activity. Applied Ecology and Environmental Research, 15(4): 525-539. doi: 10.15666/aeer/ 1504_525539.

\section{Web sources / Other sources}

[1] United Nations, Department of Economic and Social Affairs, Population Division (2019): World Urbanization Prospects: The 2018 Revision (ST/ESA/SER.A/420). United Nations, New York.

[2] COMNAP, and contributors (2017): Antarctic Station Catalogue. Christchurch, New Zealand, $154 \mathrm{p}$.

[3] BAS (British Antarctic Survey) (2004): Antarctica, 1:10000000 scale map. BAS (Misc) 11. Cambridge: British Antarctic Survey.

[4] ASPA № 127 - Management Plan for Antarctic Specially Protected Area No. 127 Haswell Island (Haswell Island and Adjacent Emperor Penguin Rookery on Fast Ice) (2016); https://www.env.go.jp/nature/nankyoku/kankyohogo/database/jyouyaku/aspa/aspa_pdf_en/127.pdf

[5] Mirny Observatory (2020); accessed Dec. 2020; http://www.aari.aq/stations/mir/mir_en.html 